\title{
KELAYAKAN FINANSIAL USATANI KEDELAI
}

\section{FINANCIAL FEASIBILITY OF SOYBEAN FARMING}

\author{
Dedi Djuliansah*1, Trisna Insan Noor², Yosini Deliana², Meddy Rachmadi² \\ ${ }^{1}$ Fakultas Pertanian, Universitas Siliwangi \\ ${ }^{2}$ Fakultas Pertanian, Universitas Padjadjaran \\ *Email: ddjuliansah@gmail.com \\ (Diterima 04-07-2019; Diterima 22-07-2019)
}

\begin{abstract}
ABSTRAK
Penelitian ini bertujuan untuk mengidentifikasi besarnya biaya, penerimaan, dan pendapatan usahatani kedelai, mengidentifikasi kelayakan usahatani kedelai, mengidentifikasi besarnya titik impas dan perubahan titik impas akibat perubahan harga jual di Kecamatan Jatiwaras Kabupaten Tasikmalaya. Metode yang digunakan dalam penelitian ini adalah metode survey, adapun data yang digunakan terdiri atas data primer dan data sekunder. Penentuan petani sampel menggunakan metode Two Stage Cluster Random Sampling, dengan ukuran sampel 65 orang dengan proporsi 27 petani di lahan sawah dan 38 orang petani di lahan darat, dari populasi petani kedelai sebanyak 185 orang. Hasil penelitian menunjukkan bahwa biaya usahatani kedelai per hektar di lahan sawah adalah $\mathrm{Rp}$ 6.680.664,34 dengan penerimaan $\mathrm{Rp}$ 8.478.139,53 dan pendapatan $\mathrm{Rp} 1.947 .475,19$ sedangkan biaya usahatani kedelai per hektar di lahan darat adalah $\mathrm{Rp}$ 4.163.487,48 dengan penerimaan $\mathrm{Rp}$ 8.342.774,57 dan pendapatan $\mathrm{Rp}$ 4.179.287,09. Usahatani kedelai di lahan darat lebih layak diusahakan dengan nilai R/C 2,01 sedangkan nilai R/C pada lahan sawah 1,28. Penerimaan minimum yang diterima petani dari usahatani kedelai agar tidak rugi dalam satu kali musim tanam sebesar Rp 251.824,26 di lahan sawah dan Rp 668.378,02 di lahan darat. Volume produksi minimum yang diterima petani dari usahatani kedelai agar tidak rugi dalam satu kali musim tanam sebesar $41,97 \mathrm{Kg}$ di lahan sawah dan $111,40 \mathrm{Kg}$ di lahan darat dan luas lahan minimum yang harus diolah oleh petani agar tidak rugi dalam satu kali musim tanam sebesar 0,03 ha di lahan sawah dan 0,08 ha di lahan darat. Penurunan harga output sebesar Rp. 1.000,00 $(16,67 \%)$ menyebabkan penerimaan minimum yang diterima petani dari usahatani kedelai agar tidak rugi dalam satu kali musim tanam sebesar Rp 413.882,65 di lahan sawah dan Rp 767.384,61 di lahan darat. Nilai margin of safety pada usahatani kedelai adalah 62,70 di lahan sawah dan 82,40 di lahan darat.
\end{abstract}

Kata kunci: Titik Impas, Kelayakan Usahatani, Lahan Sawah, Lahan Darat Kedelai

\begin{abstract}
This study aims to identify the cost, revenue, and income of soybean farming, identify the feasibility of soybean farming, identify the breakeven point and change the break-even point due to changes in selling prices in Jatiwaras District, Tasikmalaya Regency. The method used in this study is a survey method, while the data used consists of primary data and secondary data. Determination of sample farmers using the Two Stage Cluster Random Sampling method, with a sample size of 65 people with a proportion of 27 farmers in paddy fields and 38 farmers in land, from a population of soybean farmers as many as 185 people. The results of this study indicate that the cost of soybean farming per hectare in paddy fields is Rp. 5,896,896.90 with receipts of Rp 8,478,139.53 and income of $R p .2,581,242.63$, while the cost of soybean farming per hectare on land is $R p$. 4,163,487.48 with receipts of 8,342,774.57 and income of Rp. 4,179,287.09. Soybean farming in land is more feasible to be cultivated with an $R$ / C value of 2.01 while the $R$ / C value in paddy fields is 1.45. Minimum acceptance received by farmers from soybean farming so as not to lose in one planting season of Rp. 63,911.14 in paddy fields and Rp. 668,378.02 in land, the minimum production volume received by farmers from soybean farming so as not to lose in one planting season is $10.65 \mathrm{Kg}$ in paddy fields and $111.40 \mathrm{Kg}$ in land and minimum land area that must be
\end{abstract}


processed by farmers so that no loss in one planting season of 0.01 ha in paddy fields and 0.08 ha on land. Decrease in output price of Rp. 1,000.00 (16.67\%) causes the minimum acceptance received by farmers from soybean farming so as not to lose in one planting season of $R p$. 100,196.38 in paddy fields and Rp. 767,384.61 on land. The margin value of safety on soybean farming is 90.53 in wetland and 82.40 in land area.

Keywords: Break-even Point, Feasibility of Farming, Paddy Fields, Soybean Land

\section{PENDAHULUAN}

Dalam kelompok tanaman pangan, kedelai merupakan komoditas terpenting ketiga setelah padi dan jagung. Selain itu, kedelai juga merupakan komoditas palawija yang kaya akan protein. Kedelai segar sangat dibutuhkan dalam industri pangan dan bungkil kedelai dibutuhkan untuk industri pakan. Kedelai berperan sebagai sumber protein nabati yang sangat penting dalam rangka peningkatan gizi masyarakat, karena selain aman bagi kesehatan juga relatif murah dibandingkan sumber protein hewani. Kebutuhan kedelai terus meningkat seiring dengan pertumbuhan jumlah penduduk dan kebutuhan bahan baku industri olahan pangan seperti tahu, tempe, kecap, susu kedelai, tauco, snack, dan sebagainya (Damardjati et al, 2005).
Sementara Nainggolan dan Rachmat (2014) menyebutkan bahwa kedelai merupakan salah satu komoditi strategis nasional, karena perannya sebagai sumber pendapatan, lapangan kerja, pembangunan perdesaan dan sumber gizi masyarakat Indonesia.

Untuk memenuhi berbagai kebutuhan kedelai baik untuk agroindustri berbahan baku kedelai dan juga konsumsi langsung tersebut, pemerintah terus berupaya meningkatkan produksi kedelai agar target swasembada kedelai dapat tercapai. Upaya tersebut diantaranya dengan dilakukannya optimasi Perluasan Areal Tanam melalui Peningkatan Indeks Pertanaman (PATPIP) kedelai dan Gerakan Penerapan Pengelolaan Tanaman Terpadu (GP-PTT) kedelai (Kementan, 2015). 


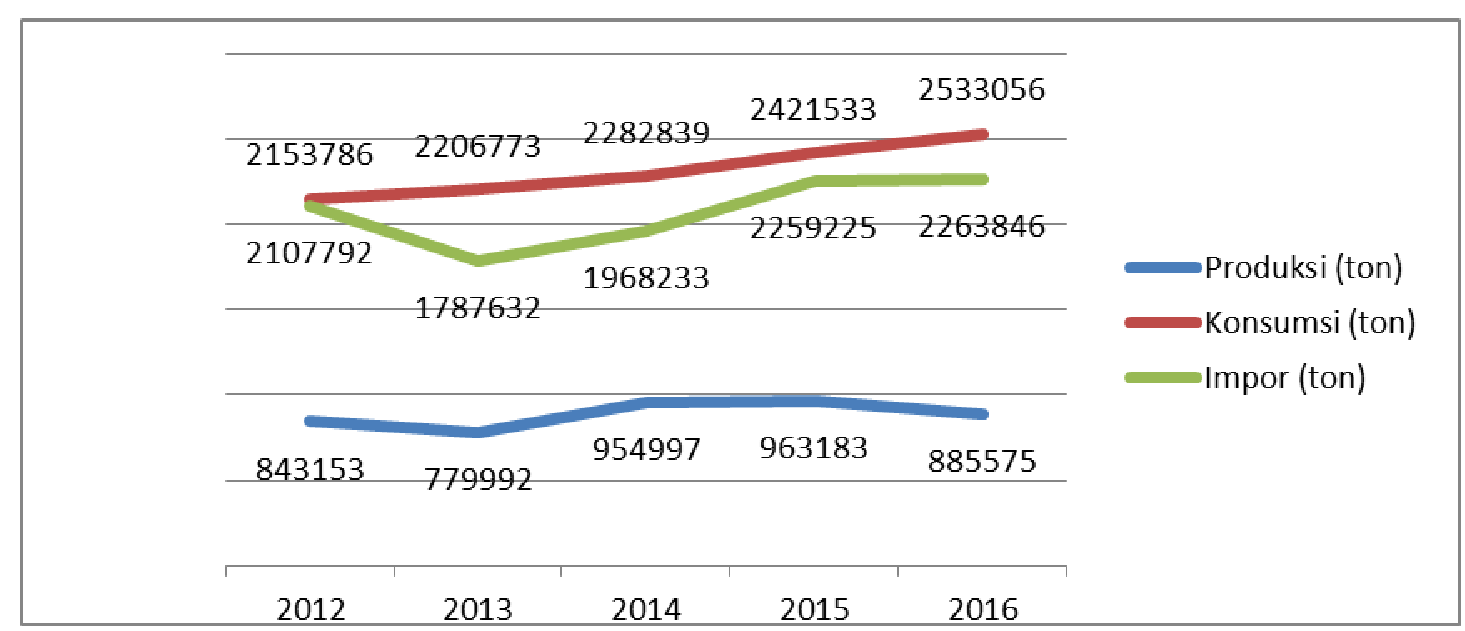

Sumber: Pusat Data dan Sistem Informasi Pertanian, 2017

Gambar 1. Perkembangan Produksi, Konsumsi dan Impor Kedelai di Indonesia, 2012-2016

Pada Gambar 1 ditunjukkan bahwa pada periode tahun 2012-2016 terjadi defisit yang semakin besar antara produksi dan konsumsi kedelai nasional yang menyebabkan tingkat impor untuk memenuhi defisit tersebut semakin besar pula. Pada periode tahun tersebut, produksi kedelai nasional meningkat dengan laju peningkatan sebesar 1,94 persen per tahun, namun pada saat yang bersamaan kebutuhan kedelai baik untuk agroindustri maupun konsumsi langsung telah meningkat sebesar 4,15 persen per tahun. Dengan demikian, untuk memenuhi laju konsumsi yang meningkat lebih dari 2 kali laju produksi tersebut, menyebabkan impor kedelai nasional meningkat sebesar 2,48 persen per tahun atau rata-rata sebesar 2 juta ton per tahun.

Dalam kondisi defisit demikian, permintaan akan kedelai dalam negeri akan terus meningkat seiring dengan bertambahnya penduduk dan meningkatnya konsumsi protein nabati per kapita yang selanjutnya mengakibatkan mendorong meningkatnya permintaan untuk bahan industri pangan seperti tahu, tempe, kecap, susu kedelai, tauco, snack dan sebagainya. Hal tersebut didukung oleh hasil penelitian Nainggolan et al (2016) yang menyatakan bahwa kebutuhan kedelai akan terus meningkat namun tidak diimbangi dengan peningkatan produksi kedelai dalam negeri, sehingga terjadi peningkatan kesenjangan antara jumlah permintaan dan penawaran produk pertanian dalam negeri. Adapun cara pemerintah untuk memenuhi kesenjangan tersebut adalah dengan melakukan impor.

Pemanfaatan lahan kering (darat) untuk budidaya kedelai merupakan salah satu solusi untuk kesinambungan produksi antar musim, karena selama ini 
penanaman kedelai lebih banyak dilakukan di lahan sawah, baik pada MT 1 maupun MT 2 setelah budidaya padi. Pengembangan kedelai di lahan kering mungkin dilakukan karena tingginya potensi perluasan lahan untuk usahatani khususnya kedelai. Keterkaitan penurunan produksi dengan semakin menyempitnya luas lahan kedelai merupakan permasalahan utama yang terjadi di Indonesia (Inu G. Ismail dan Suyatna Effendi, 1985). Faktor lahan sangat berpengaruh terhadap produksi, sejalan dengan penelitian Rizma Aldillah (2014), yang menunjukkan bahwa produksi secara nyata dipengaruhi luas areal dan produktivitas.

Berdasarkan uraian di atas maka penelitian ini bertujuan untuk 1) Mengidentifikasi besarnya biaya, penerimaan, dan pendapatan usahatani kedelai. 2) Mengidentifikasi kelayakan usahatani kedelai. 3) Mengidentifikasi besarnya titik impas. 4) Perubahan titik impas akibat perubahan harga jual.

\section{METODE PENELITIAN}

Data yang diperlukan pada penelitian ini adalah data primer dan data sekunder. Data primer yang diperoleh dari hasil wawancara dengan petani yang ditetapkan sebagai responden dengan menggunakan instrumen penelitian berupa kuesioner dan hasil pengamatan langsung di lapangan.

Data sekunder diperoleh dari berbagai instansi seperti: Dinas Pertanian, BPS, kecamatan, desa, laporan hasil penelitian terdahulu dan lain-lain. Selain petani responden, juga diwawancarai Penyuluh Pertanian Lapangan.

Metode yang digunakan dalam penelitian ini adalah metode survey pada petani kedelai di Kecamatan Jatiwaras, Kabupaten Tasikmalaya, Provinsi Jawa Barat. Teknik pengambilan sampel dilakukan dengan cara Two Stage Cluster Random Sampling, dengan ukuran sampel 65 orang dengan proporsi 27 petani di lahan sawah dan 38 orang petani di lahan darat, dari populasi petani kedelai sebanyak 185 orang. Untuk menentukan besarnya biaya total, penerimaan dan pendapatan dihitung dengan rumus sebagai berikut:

1) Analisis Biaya (Suratiyah, 2006)

$\mathrm{TC}=\mathrm{TFC}+\mathrm{TVC}$

dimana:

$\mathrm{TC}=$ Total cost

$\mathrm{TFC}=$ Total fixed cost

$\mathrm{TVC}=$ Total variable cost

2) Analisis Penerimaan (Rodjak, 2006)

$\mathrm{TR}=\mathrm{Hy} . \mathrm{Y}$

dimana:

$\mathrm{TR}=$ Total revenue

$\mathrm{Y}=$ kuantitas 
Hy $=$ Price

3) Analisis Pendapatan (Suratiyah, (2006)

$\pi=\mathrm{TR}-\mathrm{TC}$

dimana:

$\pi=$ pendapatan

$\mathrm{TR}=$ Total revenue (penerimaan total)

$\mathrm{TC}=$ Total $\cos t$ (biaya total)

4) Titik impas (Break Even Point)

a. Titik impas penerimaan

(Suratiyah, 2006)

$$
B E P_{n p}=\frac{\text { Biaya Tetap Total }}{1-\frac{\text { Biaya Variabel Total }}{\text { Nilat Penjualan }}}
$$

b. Titik impas volume produksi

(Suratiyah, 2006)

$$
B E P_{v p}=\frac{\text { BEP Penerimaan }(\mathrm{Rp})}{\text { Harga }(\mathrm{Rp} / \mathrm{Kg})}
$$

c. Titik impas luas lahan (Suratiyah, 2006)

$$
B E P_{L I}=\frac{\text { BEP unit }}{\text { Produktivitas }}
$$

5) Analisis Sensitivitas

$A=\frac{\text { Biaya Tetap X Nilai Penjualan }}{\text { Nilai Penjualan - Biaya Variabel }}$

6) Margin of safety (Munawir, 2004)

$M O S=\frac{\text { Penjualan Direncanakan }- \text { Penjualan } B E P}{\text { Penjualan yang Direncanakan }} X 100$

\section{HASIL DAN PEMBAHASAN}

\section{a. Analisis Usahatani Kedelai di Kecamatan Jatiwaras}

Usahatani kedelai di lahan darat memiliki luas lahan rata-rata lebih luas dibandingkan lahan sawah dengan rata- rata luas lahan darat sebesar 0,46 hektar dan rata-rata luas lahan sawah sebesar 0,08 hektar. Menurut Soekartawi (1987), lahan pertanian akan mempengaruhi skala usahatani dan akhirnya akan mempengaruhi usahatani tersebut efisien atau tidak, sedangkan menurut Mubyarto (1989), lahan pertanian merupakan faktor produksi paling penting dalam usahatani.

Perbedaan agroekosistem dan luas lahan akan berpengaruh juga pada input produksi yang digunakan, seperti benih, pupuk, pestisida, dan tenaga kerja, dengan perbedaan input yang digunakan maka biaya usahatanipun akan berbeda. Besarnya biaya, penerimaan, pendapatan, $\mathrm{R} / \mathrm{C}$ dari usahatani kedelai dihitung dalam satu kali musim tanam (3 bulan), untuk lebih jelasnya rata-rata penggunaan biaya produksi kedelai di lahan sawah dan lahan dan lahan darat disajikan pada Tabel 1. 
KELAYAKAN FINANSIAL USATANI KEDELAI

Dedi Djuliansah, Trisna Insan Noor, Yosini Deliana, Meddy Rachmadi

Tabel 1. Rata-rata Penerimaan, Biaya Produksi, Pendapatan Usahatani dan R/C di Lahan Sawah dan Lahan Darat Per Satu Musim Tanam

\begin{tabular}{|c|c|c|c|c|}
\hline \multirow{2}{*}{$\begin{array}{c}\text { Uraian } \\
\text { (Descriptions) }\end{array}$} & \multicolumn{2}{|c|}{ Lahan Sawah $(0,08)$} & \multicolumn{2}{|c|}{ Lahan Darat $(0,46)$} \\
\hline & Biaya (Rp) & Persen (\%) & Biaya (Rp) & Persen (\%) \\
\hline \multicolumn{5}{|l|}{ A. BIAYA VARIABEL } \\
\hline 1. Bibit/Benih/Seeds $(\mathrm{Kg})$ & $35.170,37$ & 7,87 & $177.894,74$ & 11,95 \\
\hline \multicolumn{5}{|l|}{ 2. Pupuk/ Fertilizers } \\
\hline a) NPK/ NPK (Rp) & - & & $135.868,42$ & 9,12 \\
\hline b) Pupuk Cair/ Liquid Fertilizer POC (Rp) & $8.222,22$ & 1,84 & $45.809,21$ & 3,08 \\
\hline c) Pupuk Organik Granul (Rp) & $11.883,33$ & 2,66 & $68.565,79$ & 4,60 \\
\hline d) Rizhobium (Rp) & $4.790,56$ & 1,07 & $27.576,32$ & 1,85 \\
\hline 3. Pestisida/ Pestisides (Rp) & $11.944,44$ & 2,67 & $68.048,68$ & 4,57 \\
\hline 4. Tenaga Kerja/ Labor Costs (Rp) & $374.814,81$ & 83,88 & $965.394,74$ & 64,83 \\
\hline Total Biaya Variabel & $446.825,73$ & 100,00 & $1.489 .157,90$ & 100,00 \\
\hline \multicolumn{5}{|l|}{ B. BIAYA TETAP/ FIX COSTS } \\
\hline a) Pajak Tanah (PBB)/ Land Tax (Rp) & - & & - & \\
\hline b) Sewa Lahan/ Land Rent (Rp) & $67.511,11$ & 79,28 & $379.815,79$ & 93,47 \\
\hline 6. Penyusutan Peralatan/Equipment Depretiations (Rp) & $17.641,98$ & 20,72 & $26.508,77$ & 6,53 \\
\hline Total Biaya Tetap & $85.153,09$ & 100,00 & $406.324,56$ & 100,00 \\
\hline Total biaya & $531.978,82$ & & $1.489 .157,90$ & \\
\hline \multicolumn{5}{|l|}{ C. PRODUKSI DAN PENERIMAAN } \\
\hline 1. Produksi $(\mathrm{Kg})$ & 112,52 & & 633,03 & \\
\hline 2. $\quad \operatorname{Harga}(\mathrm{Rp})$ & 6.000 & & $6.000,00$ & \\
\hline 3. Total Penerimaan $(\mathrm{Rp})$ & $675.111,11$ & & $3.798 .157,89$ & \\
\hline D. Keuntungan (TR-TC) & $155.076,73$ & & $1.902 .675,44$ & \\
\hline $\mathrm{R} / \mathrm{C}:(\mathrm{TR} / \mathrm{TC})$ & 1,28 & & 2,01 & \\
\hline
\end{tabular}

Tabel 2. Penerimaan, Biaya Produksi, Pendapatan Usahatani dan R/C di Lahan Sawah dan Lahan Darat Per Hektar Per Satu Tabel 2. Penerimaan,
Musim Tanam

\begin{tabular}{|c|c|c|c|c|}
\hline \multirow{2}{*}{$\begin{array}{c}\text { Uraian } \\
\text { (Descriptions) }\end{array}$} & \multicolumn{2}{|c|}{ Lahan Sawah } & \multicolumn{2}{|c|}{ Lahan Darat } \\
\hline & Biaya (Rp) & Persen (\%) & Biaya (Rp) & Persen (\%) \\
\hline \multicolumn{5}{|l|}{ A. BIAYA VARIABEL } \\
\hline 1. Bibit/Benih/Seeds (Rp/Ha) & $441.674,42$ & 7,87 & $390.751,45$ & 11,95 \\
\hline \multicolumn{5}{|l|}{ 2. Pupuk/Fertilizers } \\
\hline a) NPK/ $N P K(\mathrm{Rp} / \mathrm{Ha})$ & - & & $298.439,31$ & 9,12 \\
\hline b) Pupuk Cair/ Liquid Fertilizer POC (Rp/Ha) & $103.255,81$ & 1,84 & $100.621,39$ & 3,08 \\
\hline c) Pupuk Organik Granul (Rp/Ha) & $149.232,56$ & 2,66 & $150.606,94$ & 4,60 \\
\hline d) Rizhobium (Rp/Ha) & $60.160,47$ & 1,07 & $60.572,25$ & 1,85 \\
\hline 3. Pestisida/ Pestisides (Rp/Ha) & $150.000,00$ & 2,67 & $149.471,10$ & 4,57 \\
\hline 4. Tenaga Kerja/ Labor Costs $(\mathrm{Rp} / \mathrm{Ha})$ & $4.706 .976,74$ & 83,88 & $2.120 .520,23$ & 64,83 \\
\hline Total Biaya Variabel & $5.611,300,00$ & 100,00 & $3.270 .982,66$ & $\mathbf{1 0 0 , 0 0}$ \\
\hline \multicolumn{5}{|l|}{ B. BIAYA TETAP/ FIX COSTS } \\
\hline a) Pajak Tanah (PBB)/ Land Tax (Rp/Ha/Msm) & - & - & - & \\
\hline b) Sewa Lahan/Land Rent(Rp/Ha/Msm) & $847.813,95$ & 79,28 & $834.277,46$ & 93,47 \\
\hline $\begin{array}{l}\text { 6. Penyusutan Peralatan/Equipment } \\
\text { Depretiations }(\mathrm{Rp} / \mathrm{Ha} / \mathrm{Msm})\end{array}$ & $221,550.39$ & 20,72 & $58.227,36$ & 6,53 \\
\hline Total Biaya Tetap & $1.069 .364,345$ & 100,00 & $892.504,82$ & 100,00 \\
\hline Total biaya & $6.680 .664,34$ & & 4.163.487,48 & \\
\hline \multicolumn{5}{|l|}{ C. PRODUKSI DAN PENERIMAAN } \\
\hline 1. Produksi & $1.413,02$ & & $1.390,46$ & \\
\hline 2. Harga & 6.000 & & $6.000,00$ & \\
\hline 3. Total Penerimaan & $8.478 .139,53$ & & $8.342 .774,57$ & \\
\hline D. Keuntungan (TR-TC) & $1.947 .475,19$ & & $4.179 .287,09$ & \\
\hline $\mathrm{R} / \mathrm{C}:(\mathrm{TR} / \mathrm{TC})$ & 1,28 & & 2,01 & \\
\hline
\end{tabular}

\section{1) Biaya Produksi Usahatani Kedelai}

Biaya tetap (fixed cost) adalah biaya yang besar kecilnya tidak dipengaruhi oleh besar kecilnya produksi. Sedangkan biaya variabel (variable cost) yaitu biaya yang besar kecilnya sangat tergantung dan besar kecilnya produksi dan sifatnya habis dalam satu kali musim tanam. Biaya usahatani kedelai baik di lahan darat maupun lahan sawah sangat dipengaruhi oleh tingkat penggunaan sarana produksi, seperti: benih, pupuk, 
pestisida, dan tenaga kerja. Tabel 1 dan 2 menunjukan, biaya penggunaan faktor produksi didominasi oleh biaya tenaga kerja sebesar 83,88 persen di lahan sawah dan 64,83 persen di lahan darat, hal ini menunjukkan curahan tenaga yang besar atau cenderung berlebih pada usahatani kedelai, hal ini akan menyebabkan tingginya biaya produksi yang harus dikeluarkan. Secara ekonomis sehingga penggunaan tenaga kerja tidak efisien sedangkan penggunaan rhizobium memiliki persentase biaya terendah yaitu 1,07 persen di lahan sawah dan 1,85 persen di lahan darat, pada dasarnya penggunaan rhizobium untuk tanaman kedelai tidak diperlukan karena akar kedelai mengandung inokulan yang dapat menyuburkan lahan.

\section{2) Penerimaan Usahatani Kedelai}

Harga jual kedelai sangat ditentukan oleh berbagai faktor, antara lain kualitas kedelai yang dihasilkan, kepada siapa petani menjual juga ketersediaan kedelai di pasar. Kelemahan mekanisme harga produk pertanian adalah harga rendah pada saat panen raya, karena pasokan berlimpah. Pada saat penelitian, harga kedelai di tingkat petani adalah Rp 6.000,00/kg. Hasil produksi per hektar untuk lahan sawah adalah $1.413,02 \mathrm{~kg}$ per hektar, dan produksi lahan darat $1.390,46 \mathrm{~kg}$. Dari harga dan produksi maka petani di lahan sawah memperoleh penerimaan sebesar Rp 8.478.139,53 dan Rp 8.342.774,57 untuk lahan darat.

Penerimaan usahatani yang tinggi belum tentu diikuti oleh pendapatan yang tinggi jika biaya produksi tinggi. Penerimaan petani kedelai lahan sawah lebih tinggi jika dibandingkan dengan petani di lahan darat hal ini disebabkan produksi kedelai di lahan sawah lebih tinggi, tapi disisi lain biaya produksi kedelai di lahan sawah juga lebih tinggi terutama penggunaan tenaga kerja.

\section{3) Pendapatan Usahatani Kedelai}

Hasil analisis pendapatan usahatani kedelai di lahan sawah dan lahan darat per hektar dapat dilihat pada Tabel 2 . Pendapatan usahatani kedelai di lahan sawah adalah Rp 1.947.475,19, rata-rata pendapatan usahatani kedelai di lahan darat adalah $\mathrm{Rp}$ 4.179.287,09, hal ini menunjukan bahwa usahatani kedelai baik di lahan sawah maupun lahan darat sama-sama menguntungkan. Pendapatan usahatani kedelai di lahan darat lebih tinggi dibandingkan lahan sawah, hal ini terutama disebabkan oleh biaya tenaga kerja usahatani kedelai di lahan darat lebih kecil. Artinya petani kedelai di lahan darat dapat lebih mengefisienkan 
biaya tenaga kerja sehingga keuntungan per hektar petani kedelai di lahan darat lebih besar jika dibandingkan dengan petani kedelai di lahan sawah.

\section{4) $R / C$ Usahatani Kedelai}

Indikator lainnya yang digunakan untuk menilai efisiensi usahatani adalah $\mathrm{R} / \mathrm{C}$, yaitu rasio antara penerimaan dan biaya yang dikeluarkan. Semakin besar $\mathrm{R} / \mathrm{C}$ maka usahatani tersebut semakin layak untuk dilakukan. $\mathrm{R} / \mathrm{C}$ rata-rata usahatani lahan sawah adalah 1,28 dan untuk usahatani lahan darat 2,01, menunjukan bahwa $\mathrm{R} / \mathrm{C}>1$ maka usahatani kedelai di Kecamatan Jatiwaras Kabupaten Tasikmalaya dikatakan layak, sejalan dengan penelitian Amar K Zakaria (2009), yang menyatakan kegiatan usahatani kedelai di tingkat petani adalah layak diusahakan karena nilai imbangan pendapatan dan biaya $(\mathrm{R} / \mathrm{C})$ adalah lebih dari satu. Bayu Nuswantara, dkk (2016) melakukan penelitian di Desa Kebinagung Kabupaten Grobogan menunjukkan nilai $\mathrm{R} / \mathrm{C}$ dari usahatani kedelai adalah 1,29.

Dengan R/C petani di lahan sawah 1,45 dan petani di lahan darat 2,01 artinya setiap rupiah biaya yang dikeluarkan akan memperoleh penerimaan sebesar 1,45 rupiah untuk petani di lahan sawah serta 2,01 rupiah untuk petani di lahan darat.

\section{b. Analisis Titik Impas (Break Even Point)}

Menurut Suratiyah (2015) Suatu perusahaan akan berada pada titik impas (break even point) apabila dalam suatu periode aktivitas usaha, tidak memperoleh laba dan tidak juga mengalami kerugian. Artinya, jika seluruh penerimaan yang diperoleh dijumlahkan, maka jumlah tersebut sama besarnya dengan seluruh biaya yang dikeluarkan. Menurut Mulyadi (2001), titik impas (break even point) adalah keadaan suatu usaha yang tidak memperoleh laba dan tidak menderita rugi. Suatu usaha dikatakan impas jika jumlah penerimaan (revenue) sama dengan jumlah biaya, atau apabila laba kontribusi hanya dapat digunakan untuk menutup biaya tetap saja, selanjutnya Munawir (2004) menyatakan bahwa Break even point adalah suatu keadaan dimana dalam operasi perusahaan, perusahaan tidak memperoleh laba dan tidak menderita rugi (Penghasilan=Total Biaya). Berdasarkan pengertian tersebut dapat diartikan bahwa yang dimaksud dengan break even point (titik impas) adalah suatu keadaan dimana perusahaan 
tidak memperoleh laba ataupun tidak menderita kerugian. Sehingga perusahaan dikatakan impas jika jumlah penerimaan yang diperoleh sama besarnya dengan jumlah biaya yang dikeluarkan.

Tabel 3. Nilai Titik Impas dan Sensitivitas Analysis

\begin{tabular}{|c|c|c|}
\hline Uraian & Nilai Lahan Sawah & Nilai Lahan Darat \\
\hline BEP NP (Rp) & $251.824,26$ & $668.378,02$ \\
\hline BEP VP (Kg) & 41,97 & 111,40 \\
\hline BEP LL (Ha) & 0,03 & 0,08 \\
\hline $\begin{array}{l}\text { S:A (Rp) } \\
\text { Dengan harga jual turun Rp. } 1000,00\end{array}$ & $413.882,65$ & $767.384,61$ \\
\hline
\end{tabular}

\section{1) Analisis Titik Impas Penerimaan}

Hasil perhitungan menunjukkan bahwa penerimaan minimum yang diterima petani dari usahatani kedelai agar tidak mengalami rugi dalam satu kali musim tanam sebesar Rp 251.824,26 di lahan sawah dan $\mathrm{Rp} 668.378,02$ di lahan darat.

\section{2) Analisis Titik Impas Volume Produksi}

Hasil perhitungan menunjukkan bahwa volume produksi minimum yang diterima petani dari usahatani kedelai agar tidak mengalami rugi dalam satu kali musim tanam sebesar 41,97 kg di lahan sawah dan $111,40 \mathrm{~kg}$ di lahan darat.

\section{3) Analisis Titik Impas Luas Lahan}

Hasil perhitungan menunjukkan bahwa luas lahan minimum yang harus diusahakan oleh petani agar tidak mengalami rugi dalam satu kali musim tanam sebesar 0,03 ha di lahan sawah dan 0,08 ha di lahan darat.

\section{c. Analisis Kepekaan (Sensitivitas Analysis)}

Jika terjadi penurunan harga $\mathrm{Rp}$ $1.000,00$ per kilogram $(16,67 \%)$, maka diperoleh nilai penerimaan sebesar $\mathrm{Rp}$ 413.882,65 di lahan sawah dan Rp $767.384,61$, agar petani tidak mengalami kerugian.

\section{d. Batas Keamanan (Margin of Safety)}

Apabila hasil penjualan pada tingkat break even point dihubungkan dengan penjualan yang dianggarkan atau pada tingkat penjualan tertentu, maka akan diperoleh informasi tentang seberapa jauh volume penjualan boleh turun sehingga perusahaan tidak mengalami kerugian. Selisih antara penjualan yang dianggarkan dengan penjualan pada tingkat break even point merupakan tingkat keamanan bagi perusahaan dalam melakukan penjualan. Menurut Munawir (2004), perbandingan/ rasio dari selisih penjualan yang 
direncanakan dikurangi dengan penjualan pada break even merupakan tingkat keamanan (margin of safety) bagi perusahaan. Margin of safety dapat memberikan informasi mengenai berapa jumlah penjualan yang direncanakan boleh turun agar perusahaan tidak menderita kerugian.

Nilai margin of safety pada usahatani kedelai adalah 62,70 di lahan sawah dan 82,40 di lahan darat. Hal tersebut menunjukkan bahwa jika jumlah penjualan yang berikutnya menurun lebih besar dari 62,70 di lahan sawah dan 82,40 di lahan darat dari penjualan saat ini, maka usaha ini akan mengalami kerugian. Kondisi ini menggambarkan bahwa penjualan kedelai berada pada 62,70 persen dan 82,40 persen di atas titik impas.

Besarnya nilai margin of safety usahatani kedelai di lahan sawah lebih tinggi dibandingkan dengan usahatani kedelai di lahan darat, yang berarti usahatani kedelai di lahan sawah memiliki tingkat keamanan (margin of safety) lebih baik dari usahatani kedelai di lahan darat, hal ini disebabkan karena usahatani kedelai di lahan sawah menggunakan input atau sarana produksi seadanya (Low Input).

\section{KESIMPULAN DAN SARAN}

Berdasarkan hasil penelitian dan pembahasan, maka dapat ditarik keimpulan sebagai berikut:

1) Biaya penggunaan faktor produksi didominasi oleh biaya tenaga kerja sebesar 83,88 persen di lahan sawah dan 64,83 persen di lahan darat, harga kedelai di tingkat petani adalah Rp. $6.000,00 / \mathrm{kg}$. Hasil produksi per hektar untuk lahan sawah adalah $1.413,02 \mathrm{Kg}$ per hektar, dan produksi lahan darat 1.390,46 Kg. Dari harga dan produksi maka petani di lahan sawah memperoleh penerimaan sebesar Rp. 8.478.139,53 dan Rp. 8.342.774,57 untuk lahan darat. Pendapatan usahatani kedelai di lahan sawah adalah Rp. 1.947.475,19, ratarata pendapatan usahatani kedelai di lahan darat adalah Rp. 4.179.287,09.

2) $R / C$ petani di lahan sawah 1,28 dan petani di lahan darat 2,01 artinya setiap rupiah biaya yang dikeluarkan akan memperoleh penerimaan sebesar 1,28 rupiah untuk petani di lahan sawah serta 2,01 rupiah untuk petani di lahan darat.

3) Penerimaan minimum yang diterima petani dari usahatani kedelai agar tidak mengalami rugi dalam satu kali musim tanam sebesar Rp251.824,26 
di lahan sawah dan Rp. 668.378,02 di lahan darat, volume sebesar 41,97 Kg di lahan sawah dan 111,40 Kg di lahan darat, luas lahan sebesar 0,03 ha di lahan sawah dan 0,08 ha di lahan darat.

4) Jika terjadi penurunan harga $\mathrm{Rp}$. 1000,00 /Kg, maka diperoleh nilai penerimaan sebesar Rp. 413.882,65 di lahan sawah dan Rp. 767.384,61, agar petani tidak mengalami kerugian.

5) Nilai margin of safety pada usahatani kedelai adalah 62,70 di lahan sawah dan 82,40 di lahan darat.

Berdasarkan kesimpulan di atas maka dapat disarankan sebagai berikut:

1) Petani tetap mempertahankan usahataninya karena masih menguntungkan dan usahatani kedelai sangat layak untuk dilakukan pengembangan.

2) Untuk lebih mengintensifkan usahatani kedelai, maka perlu dilakukan secara agribisnis dan kemitraan, sehingga mudah dalam memperoleh sarana produksi pertanian dan pemasaran.

\section{DAFTAR PUSTAKA}

Badan Pusat Statistik. 2017. Statistik Indonesia 2017. Katalog: 1101001. https://www.bps.go.id/website/pdf publikasi/Statistik-Indonesia2017.pdf. Diakses pada Agustus 2018.

Damardjati, D.S., Marwoto, D.K.S. Swastika, D.M. Arsyad dan Y. Hilman. 2005. Prospek dan Arah Pengembangan Agribisnis Kedelai. Badan Penelitian dan Pengembangan Pertanian. Departemen Pertanian. Jakarta

Kementrian Pertanian. 2015. Rencana Strategis Kementrian Pertanian Tahun 2015-2019. http://www.pertanian.go.id.

Diakses tanggal 12 Desember 2017. Mubyarto. 1989. Pengantar Ekonomi Pertanian. Jakarta: LP3ES.

Sahara, D dan Sahardi. 2005. Efisiensi Faktor Produksi Lada pada Pola Usahatani Integrasi dan Pola Tradisional di Sulawesi Tenggara. Balai Pengkajian Teknologi Pertanian Sulawesi Tenggara Jln. M. Yamin No 89 Puwatu-Kendari.

Soekartawi,1987. Prinsip Dasar Ekonomi Pertanian (Teori Dan Aplikasinya). Rajawali: Rajawali.

Sri Sulastri. 2011. Analisis Usahatani Kedelai (Glycine max L.) yang Berkelanjutan di Kecamatan Sukorejo Kabupaten Ponorogo. Program Magister Pengelolaan Sumberdaya Lingkungan Dan Pembangunan Pasca Sarjana Universitas Brawijaya Malang, Fakultas Pertanian, Universitas Brawijaya Malang.

Suratiyah, K. 2006. Ilmu Usahatani. Jakarta: Penebar Swadaya. 